\title{
セメント硬化体のヤング率およびポアソン比の相対湿度依存性 YOUNG'S MODULUS AND POISSON'S RATIO OF HARDENED CEMENT PASTE UNDER DIFFERENT RELATIVE HUMIDITY
}

\author{
堀口直也*, 五十嵐 豪*, 丸山一平** \\ Naoya HORIGUCHI, Go IGARASHI and Ippei MARUYAMA
}

\begin{abstract}
Young's modulus, Poisson's ratio, and bulk modulus of hardened cement under controlled different relative humidities were measured by ultrasonic method as well as direct tensile loading test. It was experimentally confirmed that Young's modulus, Poisson's ratio, and bulk modulus of hardened cement paste decreased as decrease in equilibrium relative humidity especially in the range above $40 \% \mathrm{RH}$. And in the range below $40 \% \mathrm{RH}$, experimental results of direct tensile loading test showed the decrease in Young's modulus and Poisson's ratio while the experimental results of ultrasonic test showed slight increase of Young's modulus and almost constant behavior of Poisson's ratio. For the decrease of Young's modulus and Poisson's ratio can be explained by the reduction of load-bearing water in the hardened cement paste due to drying, and slight increase under 40\%RH by ultrasonic test can be explained by the increase of Si-O network of C-S-H due to drying.
\end{abstract}

Keywords : Hardened Cement Paste, Moisture content, Young's Modulus, Poisson's ratio, Bulk Modulus セメント硬化体, 含水率, ヤング率，ポアソン比，体積弾性率

\section{1. はじめに}

環境負荷の低減を求める動きから，近年は構造物の高耐久化が望 まれている。コンクリートの長寿命化には中性化，塩害，アルカリ 骨材反応といったコンクリートの化学的劣化のみでなく, 強度の長 期的な増進，乾燥収縮およびクリープ変形の増大など力学的物性の 経時変化を把握し，必要に応じて制御することも重要である。しか し, 力学的物性の経時変化についての研究は強度や乾燥収縮, クリ ープなどの報告が主であり 1)，長期的な乾燥による水分逸散を考虑 したヤング率，ポアソン比の変化に関する報告は極めて少ないのが 現状である。

コンクリートの乾燥によるヤング率の変化について，岡島ら 2)が コンクリートのヤング率は含水率の上昇に伴って増大するという報 告を行っている。また Wittmann ${ }^{3}$ は, セメント硬化体のヤング率 は平衡相対湿度の低下とともに減少していくが, ある相対湿度で極 小值をとり,それ以下の湿度では再び上昇することを報告している。 また Sereda ら ${ }^{4}$ は，吸着プロセス上では相対湿度 $0 \%$ から $50 \%$ の 範囲ではセメント硬化体のヤング率に変化は生じないものの, 高湿
度領域ではヤング率は増大するとしている。このように，コンクリ 一トやセメント硬化体の乾燥によるヤング率の変化はいまだ統一的 な見解が見いだされていないのが現状である。

ヤング率や弾性係数を求める方法には, コンクリートに外力荷重 を加えた時の変形量から求まる静弾性係数試験，共振法や超音波法 により求める動弾性係数試験が存在する。超音波試験は構造物を破 壊せずに物性が把握できる非破壊試験として注目されており，コン クリートを透過した波の伝播時間を用いる透過法や回折した波の伝 播時間を用いる反射法がある。透過法では縦波伝播速度とヤング率 の関係性についての報告が広く行われており，近年では縦波および 横波伝播速度から試験体のポアソン比, ヤング率を算出する手法も 研究が進められている。河角 5)はさまざまな水セメント比, 材齢の セメント硬化体を用いた超音波伝播試験による動弹性係数から静弾 性係数を求める式を示している。また，Abeele ${ }^{6)}$ らは極若材齢時か らのコンクリートのヤング率, ポアソン比の経時的変化の報告を行 っている。

本研究では, 各平衡相対湿度に達した試験体を用いて超音波試験

表 1 セメントの性質

\begin{tabular}{|c|c|c|c|c|c|c|c|c|c|c|c|c|}
\hline & \multirow{2}{*}{$\begin{array}{c}\text { 密度 } \\
{\left[\mathrm{g} / \mathrm{cm}^{3}\right]}\end{array}$} & \multirow{2}{*}{$\begin{array}{c}\text { 比表面積 } \\
{\left[\mathrm{cm}^{2} / \mathrm{g}\right]}\end{array}$} & \multirow{2}{*}{$\begin{array}{l}\text { ig.loss } \\
(\%)\end{array}$} & \multicolumn{9}{|c|}{ 化学成分（\%mass） } \\
\hline & & & & $\mathrm{SiO}_{2}$ & $\mathrm{Al}_{2} \mathrm{O}_{3}$ & $\mathrm{Fe}_{2} \mathrm{O}_{3}$ & $\mathrm{CaO}$ & $\mathrm{MgO}$ & $\mathrm{SO}_{3}$ & $\mathrm{Na}_{2} \mathrm{O}$ & $\mathrm{K}_{2} \mathrm{O}$ & $\mathrm{Cl}^{-}$ \\
\hline 普通ポルトランドセメント & 3.16 & 3110 & 0.64 & 21.8 & 4.49 & 2.90 & 63.9 & 1.84 & 2.26 & 0.20 & 0.38 & 0.007 \\
\hline
\end{tabular}

* 名古屋大学大学院環境学研究科都市環境学専攻 博士前期課程 $\cdot$ 大学院生

** 名古屋大学大学院環境学研究科都市環境学専攻 准教授・博士 (工学)

Graduate Student, Dept. of Environmental Eng. and Arch., Nagoya Univ. Assoc. Prof., Dept. of Environmental Eng. and Arch., Nagoya Univ., Dr. Eng. 
および直接引張試験からヤング率, ポアソン比の測定を行い, ヤン グ率等の力学的物性值の変化とそれが及ぼす影響について考察を行 った。

\section{2. 実験概要}

\section{1 使用材料および調合}

超音波試験および直接引張試験には研究用普通ポルトランドセメ ント（記号 N）を用いた。セメントの物性を表 1 に示す。

超音波試験に用いた試験体は水セメント比 $0.55,0.40,0.30$ (記号 はそれぞれ N55，N40，N30)で $3 \times 13 \times 300 \mathrm{~mm}$ の鋼製型枠に打設 し，N55，N40，N30 はそれぞれ材齢 5 日，4 日，2 日で脱型した。 脱型後は恒温室 $\left(20 \pm 2^{\circ} \mathrm{C}\right)$ で材齢 28 日まで飽和水酸化カルシウム 溶液中で水中養生を行い, 以後は乾燥開始材齢まで湿布養生にて養 生した。試験体は基準となる長さ, 質量を測定した後, 相対湿度の 異なる飽和水溶液で調湿したデシケータ内に静置し, 1 年間の調湿 を行った後, 再び試験体長さおよび質量を測定し, ひずみと含水率 を算出した。デシケータ内の湿度はそれぞれ $95,85 ， 75 ， 70 ， 60$, $43 ， 23 ， 11 \% \mathrm{RH}$ である。使用した飽和水溶液の相対湿度を表 2 に 示寸。また， $95 \% \mathrm{RH}$ 試験体を浸水させた上で減圧機を用いて飽水 状態としたものを $100 \%$ RH として測定を行った。0\%RHについて は試験体をマッフル炉により $105^{\circ} \mathrm{C}$ で 24 時間乾燥させることによ り行った。

直接引張試験に用いた試験体は水セメント比 $0.55,0.40$ で $3 \times 22$ $\times 300 \mathrm{~mm}$ の鋼製型枠に打設し, それぞれ材齢 4 日と 3 日で脱型を 行った。脱型後は恒温室 $\left(20 \pm 2^{\circ} \mathrm{C}\right)$ で飽和水酸化カルシウム溶液 による水中養生を行い, 試験体長さを $15 \mathrm{~cm}$ に成形した後, 基準と なる試験体長さ, 質量を測定した。その後, 相対湿度 $100 \%$ とする 試験体は水中養生を継続し，80，60，40\%RH に調湿する試験体は 各湿度に調湿したデシケータ内に入れ 3 ケ月以上調湿を行った後, 再び試験体長さと質量を測定しひずみ，含水率を算出した。デシケ 一夕内の相対湿度は土 $3 \% \mathrm{RH}$ で制御し, 調湿には水酸化ナトリウム を使用した 7)。また, 相対湿度 $0 \% \mathrm{RH}$ とする試験体は基準長さ, 質 量を測定後マッフル炉で $105^{\circ} \mathrm{C}$ 乾燥を 24 時間行い, 長さおよび質 量を測定後,アルミ袋に入れ密封状態で保管した。

本試験では十分な期間調湿を行い, 代表的なサンプルを用いて質 量変化が無くなったのを確認した上で, 試験体内部が外気湿度と平 衡に達した状況において試験を実施した。そのため本検討では試験 体内部は水分分布やそれに起因する物性について均質な状況にある ものと考えることができる。

\section{2 超音波試験}

表 2 各種塩の飽和水溶液における相対湿度

\begin{tabular}{|c|c|}
\hline 溶質 & 相対湿度 $(\%)$ \\
\hline $\mathrm{KNO}_{3}$ & 95 \\
\hline $\mathrm{KCl}$ & 85 \\
\hline $\mathrm{NaCl}$ & 75 \\
\hline $\mathrm{KI}$ & 70 \\
\hline $\mathrm{NaBr}$ & 60 \\
\hline $\mathrm{K}_{2} \mathrm{CO}_{3}$ & 43 \\
\hline $\mathrm{CH}_{3} \mathrm{COOK}$ & 23 \\
\hline $\mathrm{LiCl}$ & 11 \\
\hline
\end{tabular}

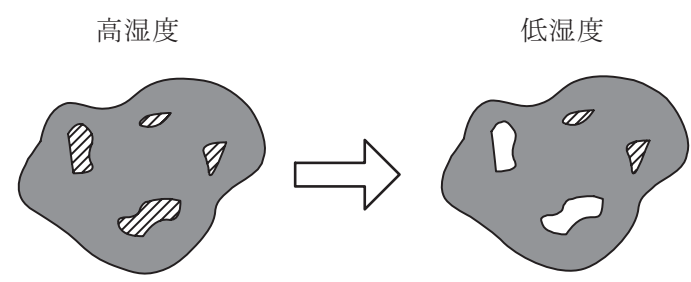

湿度低下により空隙内から水が逸散する ことで，みかけの密度が低下する。

図 1 見かけの密度の概念図

超音波試験には透過法と反射法があるが，本論文では透過法によ り超音波到達時間を測定した。測定装置としては PanametricsNDT TM 超音波探触子（縦波用：V103-RM，横波用：V153-RM)， Panametrics-NDTTM パルサレシーバー5077PR (OLYMPUS 社製), およびデジタルオシロスコープ TDS2012B（Tektronix 社製）を使 用した。測定条件は, パルス発振電圧 : $-400 \mathrm{~V}$, 探触子周波数 : $1.0 \mathrm{MHz}$ ，パルス繰返し周波数： $100 \mathrm{~Hz}$ である。接触媒質には試験 体内部への浸透を抑えるため縱波, 横波測ともに粘性の高いカップ ラントを使用した。

縦波到達時間および横波到達時間は送信用，受信用探触子を試験 体の両側から押しあて測定した透過波形と，試験体を挟まず測定し たリファレンス波形により求めた。縦波および横波の到達時間は, 正の第 1 波形における極大值となる点の時間を用い，透過波形とリ ファレンス波形の時間の差分を到達時間とした。この到達時間を, ノギス（最小目盛り $0.05 \mathrm{~mm}$ ）により測定した試験体厚さから除し て縦波速度および横波速度が算出できる。この值を用い, ヤング率, ポアソン比, 剛性率, 体積弾性率を算出した。ここで, セメント硬 化体は図 1 に示寸ように含水率に依存して見かけの密度が異なるた

表 3 セメント硬化体の性質

\begin{tabular}{|c|c|c|c|c|}
\hline & $\begin{array}{c}\text { 飽水時の見かけの密度 } \\
\left(\mathrm{g} / \mathrm{cm}^{3}\right)\end{array}$ & $\begin{array}{c}\text { 飽和質量含水率 } \\
(\mathrm{g} / \mathrm{g})\end{array}$ & $\begin{array}{c}\text { 飽和体積含水率 } \\
\left(\mathrm{cm}^{3} / \mathrm{cm}^{3}\right)\end{array}$ & $\begin{array}{l}\text { 真密度 } \\
\left(\mathrm{g} / \mathrm{cm}^{3}\right)\end{array}$ \\
\hline N55 超音波試験(N55U) & 1.93 & 0.285 & 0.428 & 2.62 \\
\hline N40 超音波試験(N40U) & 2.12 & 0.192 & 0.341 & 2.70 \\
\hline N30 超音波試験(N30U) & 2.23 & 0.144 & 0.280 & 2.71 \\
\hline N55 直接引張試験 $(\mathrm{N} 55 \mathrm{~T})$ & 1.91 & 0.294 & 0.433 & 2.64 \\
\hline $\mathrm{N} 40$ 直接引張試験 $(\mathrm{N} 40 \mathrm{~T})$ & 2.05 & 0.210 & 0.355 & 2.62 \\
\hline
\end{tabular}




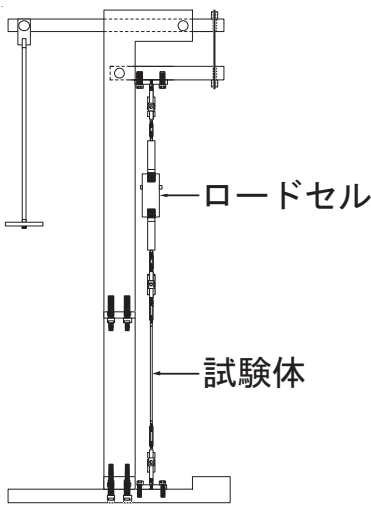

図 2 引張試験機

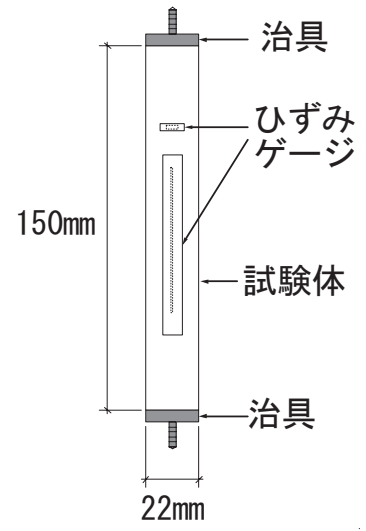

図 3 試験体詳細図
め, ヤング率の導出には後に示寸図 5 の実験結果から算出した各湿 度における見かけの密度を用いた。

\section{3 直接引張試験}

直接引張試験の載荷は試験体両端にエポキシ系接着剤で治具を接 着することにより行った。試験機は図 2 に示したテコ式引張試験機 であり, 荷重は試験体上部に接続したロードセル(測定範囲 $500 \mathrm{~N}$, 精度 $\pm 0.5 \%)$ により測定した。本試験機では試験体に曲げモーメン トが作用することを抑えるため, 試験機と試験体, ロードセルの接 続部にユニバーサルジョイントを使用した。試験体のひずみ測定は 縦方向および横方向に貼り付けたひずみゲージにより測定した（図 3 )。また, 載荷時に試験体から水分の逸散が生じないよう, ひずみ ゲージを妨げない処理をした上からアルミ粘着テープで封縅を施し た。

\section{4 セメント硬化体の物性值}

セメント硬化体の飽水状態における見かけの密度は, セメント硬 化体を表面乾燥状態として, アルキメデス法により測定した。その 後, 表面乾燥状態の試験体を $105^{\circ} \mathrm{C} て ゙ 24$ 時間乾燥させて, 質量減 量を測定し, 飽和含水率を求めた。乾燥により蒸発した水はセメン 卜硬化体中では大気圧下の体積と等しかったものとし, 各相対湿度 における見かけの密度およびセメント硬化体の真密度を算出した。

\section{3. 実験結果と考察}

\section{1 セメント硬化体の物性と含水率}

本試験に使用したセメント硬化体の性質を表 3 に示す。これらの 值は, 超音波試験の密度の評価に用いた。以降の議論では超音波試 験に用いた試験体の結果を $\mathrm{U}$, 直接引張試験に用いた試験体の結果

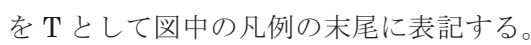

超音波試験に使用した試験体の相対湿度とひずみの関係を図 4 , 超音波および直接引張試験に使用した試験体の脱着線を図 5 に示す。 脱着線における相対湿度 $0 \% \mathrm{RH}$ では含水率は $0(\mathrm{~g} / \mathrm{g})$ として扱った。 ひずみは水セメント比が小さいほど収縮量が小さくなる傾向を示し た。含水率においては, 各試験体とも相対湿度 $11 \%$ から相対湿度 $60 \%$ 範囲までは水セメント比にかかわらずほぼ同様の值を示し, $60 \%$ 以上では水セメント比が大きいほど含水率が高くなる傾向が 確認された。この傾向は岸ら ${ }^{8}$ の既往の研究と同様であった。

\section{2 ヤング率およびポアソン比}

超音波試験により測定した縦波速度 $V_{p}(\mathrm{~km} / \mathrm{s})$, 横波速度 $V_{s}(\mathrm{~km} / \mathrm{s})$

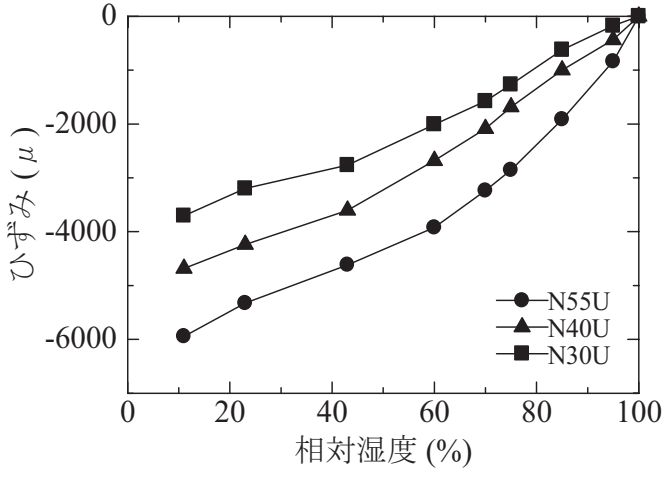

図4 超音波試験に用いた相対湿度とひずみの関係

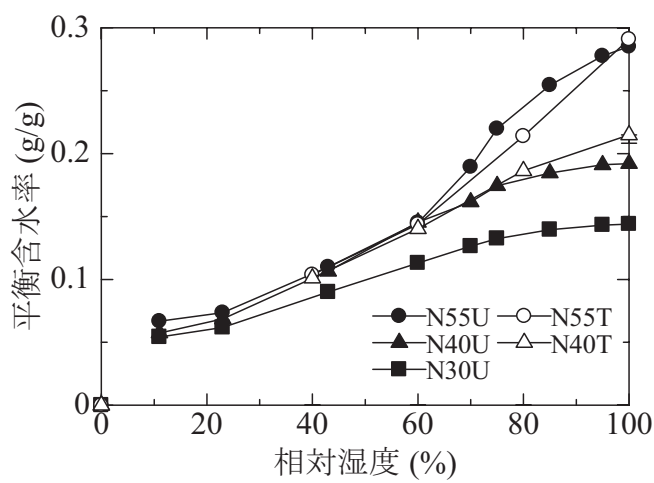

図 5 相対湿度と平衡含水率の関係

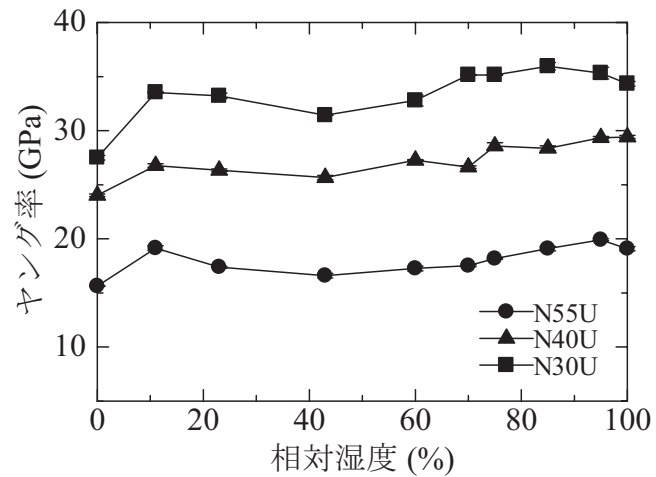

図 6 超音波試験における相対湿度とヤング率の関係

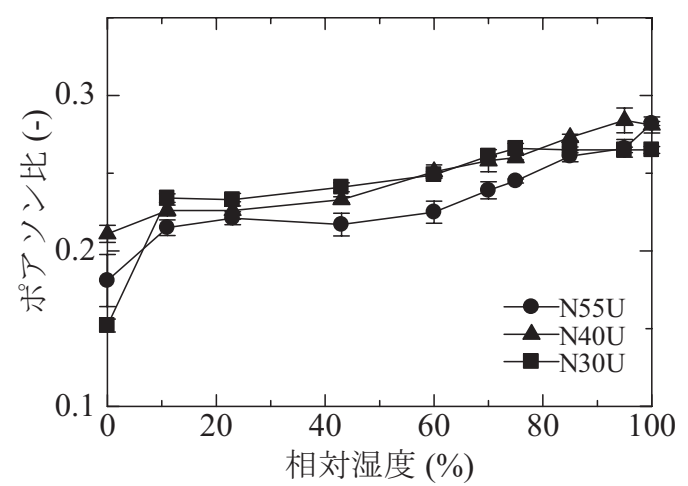

図 7 超音波試験における相対湿度とポアソン比の関係 
および密度 $\rho\left(\mathrm{g} / \mathrm{cm}^{3}\right)$ よりポアソン比 $v(-)$, ヤング係数 $E_{w}(\mathrm{GPa})$ を以

下の式により算出した ${ }^{9)}$ 。

$$
\begin{gathered}
v=\frac{1-2\left(V_{s} / V_{p}\right)}{2-2\left(V_{s} / V_{p}\right)} \\
E_{w}=V_{p}^{2} \rho \frac{(1+v)(1-2 v)}{1-v}
\end{gathered}
$$

ここで $\rho$ は各相対湿度における見かけの密度であり, 各湿度での 試験体質量 $m(\mathrm{~g})$, 飽和質量含水率 $w_{s}(\mathrm{~g} / \mathrm{g})$ お よび試験体の絶乾質量 $m_{0}(\mathrm{~g})$ より次式で求めた。

$$
\rho=\frac{1+\left(m-m_{0}\right) / m_{0}}{1+w_{s}}
$$

(1)，(2)式より求めたヤング率，ポアソン比と相対湿度の関係を図 6 および図 7 に示す。ヤング率, ポアソン比は試験体の 3 点の平均 值より求め, 図中のエラーバーは標準偏差を表している。ヤング率 は高湿度領域においては相対湿度の減少とともに低下していくが, 相対湿度 $40 \%$ 付近で極小值をとり, さらに湿度が低下していくとヤ ング率は上昇していく結果となった。なお， $105^{\circ} \mathrm{C} て ゙ 24$ 時間という 長い乾燥を経た $0 \% \mathrm{RH}$ では急激にヤング率が低下しており,これは 強い乾燥によって生じるマイクロクラックの影響ではないかと推察 された。0\%RHの条件を除けば，ヤング率は乾燥の程度により約 7 〜 $13 \%$ の低下が確認された。本傾向は, Wittmann ${ }^{3)}$ の研究と同様 であった。

ポアソン比に関しても, 相対湿度の減少とともに低下していく傾 向が確認された。一方で, 相対湿度 $40 \%$ 以下では, ほぼ横ばいに近 い值を示した。ただし， $0 \% \mathrm{RH}$ の条件で急激に值が小さくなるのは ヤング率と同様である。

ポアソン比に関しては水セメント比による違いはほとんど確認さ れておらず, 固相量の大小よりも, 水の影響が大きいものと推察さ れた。

ヤング率およびポアソン比より求めた剛性率および体積弾性率と 相対湿度の関係を図 8 , 図 9 に示寸。剛性率 $G(\mathrm{GPa})$, 体積弾性率 $K(\mathrm{GPa})$ は以下の式より導出した。

$$
\begin{aligned}
& G=\frac{E_{w}}{2(1+v)} \\
& K=\frac{E_{w}}{3(1-2 v)}
\end{aligned}
$$

剛性率および体積弾性率においても相対湿度 $40 \%$ 付近まで低下 し，その後わずかに上昇する傾向が確認された。ただし剛性率の感 度は, 非常に小さい。剛性率, 体積弾性率もヤング率と同様に水セ メント比が支配的ではあるが, 体積弾性率に関しては最大值からの 低下率は約 20～30\% と大きく, 含水率の影響は無視できないもので あると考えられる。

直接引張試験により求めたヤング率, ポアソン比, 剛性率, 体積 弾性率と超音波試験により求めた各值を同一グラフ上にプロットし たものを図 10，11，12，13 に示す。直接引張試験における各值は試 験体 3 本による平均值を用いた。両試験における試験体の材齢およ び養生方法の違いはあるが, 動弾性係数は静弹性係数に比べ高い值 をとることが言われていることから ${ }^{5)}$, 本検討では各平衡相対湿度 における傾向の比較を目的に同一図に記載を行った。本試験におい

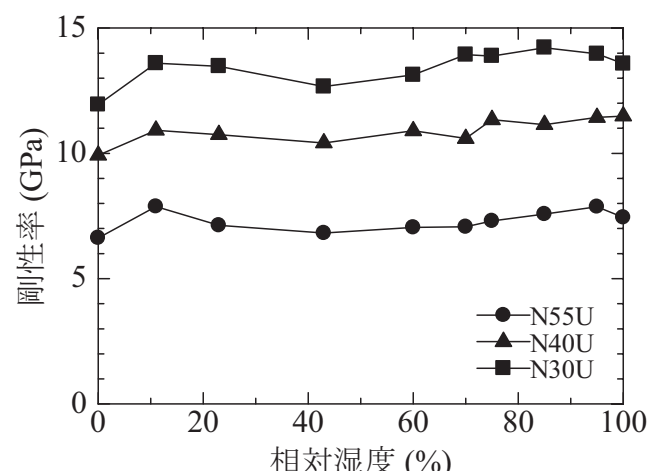

図 8 超音波試験における相対湿度と剛性率の関係

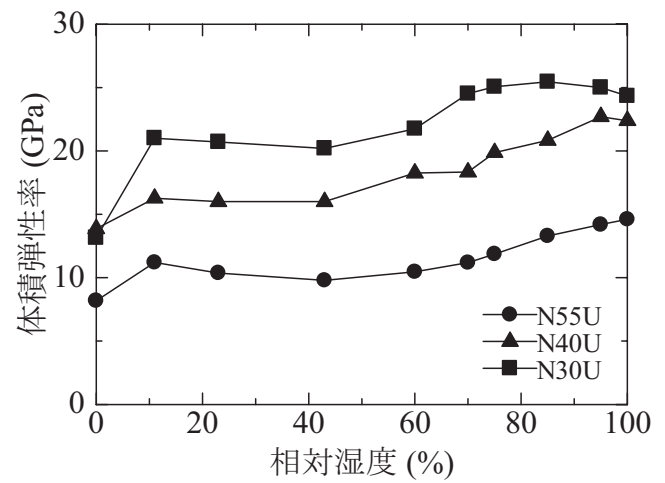

図 9 超音波試験における相対湿度と体積弾性率の関係

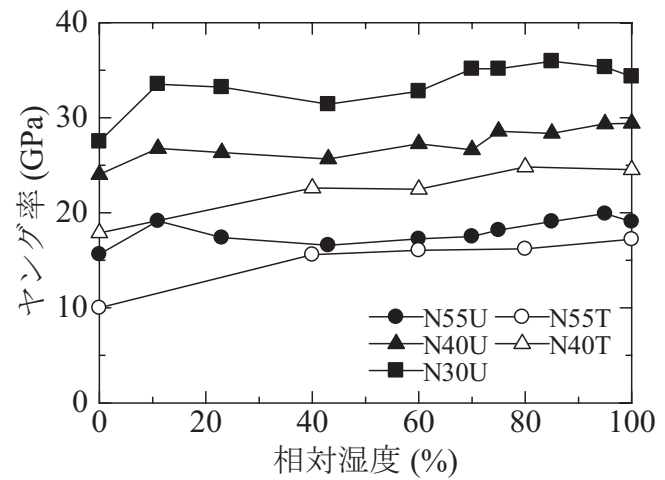

図 10 ヤング率の相対湿度依存性の試験方法による比較

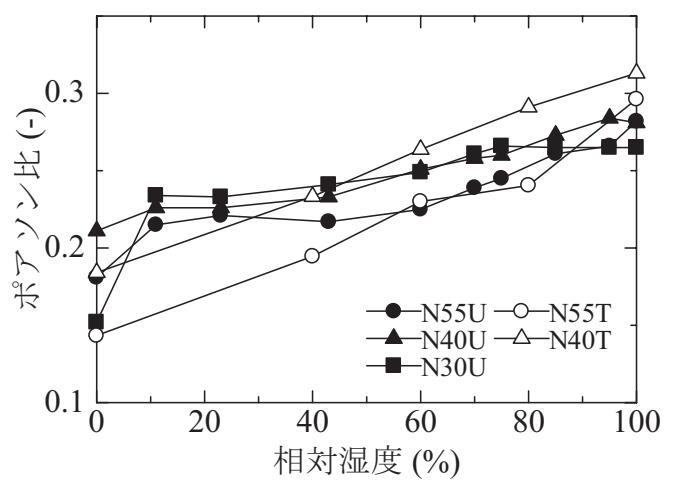

図 11 ポアソン比の相対湿度依存性の試験方法による比較 
ても引張試験のヤング率は超音波試験に比べ小さい值を示している が, ヤング率, ポアソン比, 体積弹性率における相対湿度 $40 \%$ 以上 の領域での傾向は同様で, 湿度の低下により各物性值は低下した。 また, 超音波試験における各物性は相対湿度 $40 \%$ 以下の低湿度領域 において上昇もしくは横ばいに推移しているのに対し, 絶乾試験体 では両試験とも各物性に大きな減少が見られた。これは試験体を $105^{\circ} \mathrm{C}$ で乾燥した際に試験体中にマイクロクラックが生じ, マイクロ クラックが載荷により進展するため他の湿度の試験体に比べひずみ が増大したことが考えられる。

相対湿度 $40 \%$ RH 以上において, セメント硬化体のヤング率が減 少した原因としては, 微小空隙内に吸着・凝縮している水が応力負 担をすることが古くから指摘されておりたとえば1)，含水率の低下によ り実質的な応力負担面積が減少したことで，応力に対するコンプラ イアンスが増加したものと考えられる。超音波の伝播速度について も同様で, 微小空隙中の水分の挙動が固体に近い振る舞いをしてお り，その水分が減少することで伝播速度が低下したものと推察され る。この多孔体中の水が超音波伝導性にどのような振る舞いをする かについては, 今後の課題としたい。一部, 考察として河角の研究 にこれらの分析があるので，参考になろう ${ }^{10)}$

低湿度領域における超音波試験によるヤング率の上昇のメカニズ ムの一つの仮説として, 低湿度領域では, セメントの水和生成物で ある C-S-H の Si-O 鎖が乾燥によって長大化することに起因すると 考えられ ${ }^{11)}$, 固相部分の超音波伝播速度が，水の低下量を上回るほ ど改善された結果として生じるというものが挙げられる。

\section{4. 考察}

\section{1 乾燥クリープとの関係}

載荷した状態でのコンクリートの乾燥はクリープ変形量を増大 させることが知られており, Day と Illston ${ }^{12)}$ は小さなセメント硬化 体であっても乾燥時にクリープひずみが増大寸ることを報告し, 乾 燥クリープは内部水分の勾配の影響ではなくセメント硬化体自体の 性質であることを報告している。また Glucklick ら ${ }^{13)}$ は試験体に乾 燥が生じない状態における稀じりクリープの含水率依存性を測定し ており, 含水率の低下によりクリープ変形量は減少し, 含水率が 0 に近い状態ではねじりクリープはほとんど生じないことを報告して いる。

乾燥クリープのメカニズムとしては，これまで応力負担する水の 散逸が原因であるとの解釈がなされ, この影響は, 除荷後のヤング 率には影響が無く, 純粋にクリープひずみの問題として評価されて きた。しかし，本論文で示したようにセメント硬化体は相対湿度 $40 \%$ 以上の範囲では含水率の低下に伴ってヤング率の低下がみられ ることから, 乾燥過程にある構造物で一定荷重をうける部材では, ヤング率の低下により変形が増大寸ることが考えられ，これが乾燥 によるクリープ増大の要因の一つであることが考えられる。また， この結果は, 硬化後の弾性挙動にも影響を及ぼし, たとえば構造物 の固有振動数が変化する, 部材の変形が大きくなることを意味して いる。このように, 乾燥条件下におけるクリープひずみ成分が何に 起因するかを理解するためにも, また, 長期的な部材の乾燥状態を 考慮した構造挙動を評価するためにも, 含水率の変化による物性の 変化は着目すべき重要な要素と考えられる。

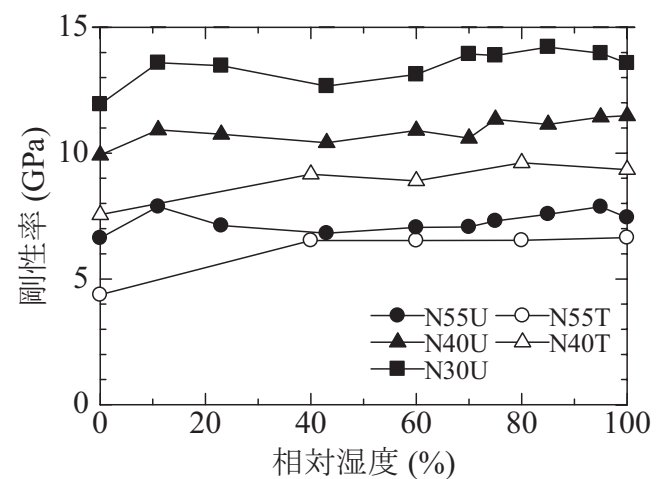

図 12 剛性率の相対湿度依存性の試験方法による比較

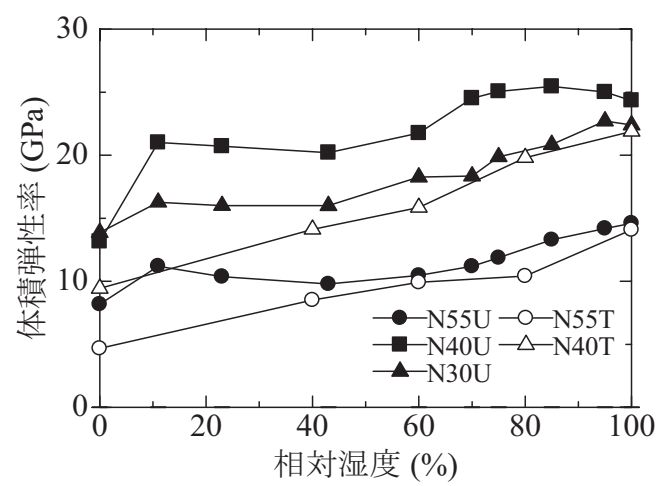

図 13 体積弾性率の相対湿度依存性の試験方法による比較

\section{2 工学的問題}

乾燥の影響によると推測されるクリープの増大は実構造物にも確 認されている。Watanabe ら ${ }^{14}$ は，月夜野大橋のスパン中央部におけ る変形が現在のクリープ評価式による予想值を大きく超えて増大し ていることを発表した。また Bazant $ら^{15)}$ も，パラオ橋の落橋事故に おいて予測式を大きく超える変形が生じた事例を報告している。構 造物のクリープ変形を考慮する上で，乾燥による硬化体の応答を考 え, 数值解析に反映させるために本研究のデータは重要な知見とな るだろう。また，工学的に長期的な供用期間に対する設計を考える のであれば，立地に応じた平均相対湿度を一つのターゲット環境と し, その環境下で調湿したコンクリートの試験体の乾燥収縮試験, 乾燥収縮が一定值に収束してからのヤング率試験, 引きつづきクリ ープ試験を行い，これらのデータを用いて使用性状や地震時の挙動 を評価することで, 安全側の評価が可能になると考えられる。この ような検討は，費用も時間もかかるため，すべての建築に求める必 要は無いが，重要構造物で長期的な利用が考えられる場合には，今 後，検討が望まれる。

\section{5. まとめ}

本研究ではセメント硬化体のヤング率，ポアソン比，岡性率，体 積弾性率の平衡相対湿度依存性を超音波試験および直接引張試験の 2 点から評価した。結果，以下の知見が得られた。

1）超音波試験において，ヤング率は相対湿度の低下に伴って減少 していき， $40 \% \mathrm{RH}$ 付近で極小值をとり，40\% RH 以下の領域 ではヤング率は再び上昇する。体積弾性率についても同様の傾 向が測定された。ポアソン比は， $40 \% \mathrm{RH}$ 以下では，ほぼ一定 
值をとる。

2）直接引張試験では，ヤング率，ポアソン比，体積弾性率は湿度 の低下に伴い，一律に低下寸る。ただし，40\%RH 以下の領域 の測定点が不足しているので，今後，0〜40\%RH の領域の挙動 については, 再度確認の必要がある。

3）超音波試験による相対湿度 $40 \%$ 以下の領域でのヤング率の増 加（伝播速度の増加）は，乾燥により $\mathrm{C}-\mathrm{S}-\mathrm{H} の \mathrm{Si}-\mathrm{O}$ 鎖長の増 大により，固体の伝播速度が大きくなることに起因すると推察 された。

\section{謝辞}

本研究の一部は, 平成 21 年度経済産業省高経年化対策強化基盤整 備事業の一環として行った。また，試験体の調湿についての助言を 戴いた岸直哉氏 (名古屋大学修了生), 試験体を提供して戴いた猪飼 陽子氏（名古屋大学修了生）に謝意を表します。

\section{参考文献}

1) Powers, T. C.: Mechanisms of shrinkage and reversible creep of hardening cement paste, in Proc. Int. Symp. "Structure of Concrete and its behavior under load", London, pp.319-344, 1965

2) 岡島達雄, 志村欣一: コンクリートの強度及びヤング係数と水分の関係, 日本建築学会大会学術講演梗概集, Vol.A, pp.799-800, 1989.10

3) Wittmann, F. H.: Interaction of Hardened Cement Paste and Water, Journal of the American Ceramic Society, Vol.56, No.8, pp. 409-415, 1973

4) Sereda, P. J., Feldman, R. F., and Swenson, E. G.: Effect of sorbed water on some mechanical properties of hydrated Portland cement paste and compacts, Highway research board, SR90, pp.58-73, 1966
5) 河角誠: コンクリートのクリープ予想式における瞬間ひずみ成分の決定 一セメントペーストの動弾性係数と静弾性係数の関係一, 電力中央研究 所報告, 研究報告: U92004, 1992

6) Abeele, K. Van Den, Desadeleer, W., Schutter, G. and Wevers, M. Active and passive monitoring of the early hydration process in concrete using linear and nonlinear acoustics, Cement and Concrete Research, Vol.39, pp.426-432, 2009

7) 丸山一平, 岸直哉 : セメント硬化体の収縮理論, 日本建築学会構造系論 文集，Vol. 74，No.642，pp.1395-1403，2009.8

8) 岸直哉, 猪飼陽子, 丸山一平：セメント硬化体の乾燥収縮ひずみに及ぼ す内部相対湿度の影響, 日本建築学会大会学術講演梗概集, A-1, 材料 施工, pp. 819-820， 2008.9

9) 三木幸蔵，わかりやすい岩石と岩盤の知識，鹿島出版会，pp.128-129, 1978

10) 河角誠，栗山武雄：セメントペースト内の超音波伝播速度を配合と材令 などから求める理論式, 電力中央研究所報告, 研究報告 : U89043, 1989

11) Aono, Y., Matsushita, F., Shibata, S. and Hama, Y.: Nano-structual changes of C-S-H in hardened cement paste during drying at $50^{\circ} \mathrm{C}$, Journal of Advanced Concrete Technology, Vol.5, No.3, pp.313-323, 2007

12) Day, R. L., Illston, J. M.: The effect of rate of drying on the drying/wetting behavior of hardened cement paste, Cement and Concrete Research, Vol.13, No.1, pp. 7-17, 1983

13) Glucklich. J, Ishai. O.: Creep mechanism in cement mortar, Journal of American Concrete Institute, Vol.59, pp.923-948, 1962.7

14) Watanabe, Y., Ohura, T., Nishio, H. and Tezuka, M.: Practical prediction of creep. Shrinkage and durability of concrete in Japan, Creep, Shrinkage and Durability Mechanics of Concrete and Concrete Structures, edt. T. Tanabe et al., CRC Press, Leiden, Vol.1, pp.529-539, 2008.9,

15) Bazant, Z. P., Li, G. H., Yu, Q.: Explanation of excessive long-time deflections of collapsed record-span box Girder Bridge in Palau, Preliminary Structure Engineering Report, No.08-09/A222e, pp.1-20, 2008 